\title{
An Unsymmetrical Iron Catalyst for the Asymmetric Transfer Hydrogenation of Ketones
}

\author{
Samantha A. M. Smith, Robert H. Morris \\ Version Post-print/accepted manuscript \\ Citation Smith, S. A., \& Morris, R. H. (2015). An Unsymmetrical Iron Catalyst \\ (published version) for the Asymmetric Transfer Hydrogenation of Ketones. Synthesis, \\ 47(12), 1775-1779.
}

Publisher's statement The final published version of this article is available through Thieme Publishing Group at http://dx.doi.org/10.1055/s-0034-1380147.

Copyright C Georg Thieme Verlag Stuttgart · New York 2015

How to cite TSpace items

Always cite the published version, so the author(s) will receive recognition through services that track citation counts, e.g. Scopus. If you need to cite the page number of the author manuscript from TSpace because you cannot access the published version, then cite the TSpace version in addition to the published version using the permanent URI (handle) found on the record page.

This article was made openly accessible by $U$ of $T$ Faculty. Please tell us how this access benefits you. Your story matters. 


\title{
Unsymmetrical Iron Catalyst for the Asymmetric Transfer Hydrogenation of Ketones.
}

\author{
Samantha A. M. Smith, Robert H. Morris* \\ Department of Chemistry, University of Toronto, 80 St. George Street, Toronto, Ontario, Canada, M5S 3H6. \\ Fax: \\ E-mail: robert.morris@utoronto.ca
}

Abstract: A new iron(II) $\left(\mathrm{Ph}_{2} \mathrm{P}-\mathrm{NH}-\mathrm{N}-\mathrm{PCy} \mathrm{H}_{2}\right)$ complex with
a dicyclohexylphosphino group trans to the $\mathrm{NH}$ group has
been found to catalyze the asymmetric transfer
hydrogenation of a variety of ketones with high
enantioselectivity.

Key words: hydrogenation, iron catalysis, chirality, ketone alcohol

The reduction of ketones to enantiopure alcohols is a very important transformation in organic synthesis as it provides valuable building blocks for the flavor, fragrance, fine chemical, and pharmaceutical industries. ${ }^{1}$ Precious metals with expensive chiral ligands are generally required for the catalytic hydrogenation of ketones, but these metals are costly and potentially toxic. ${ }^{2}$ Thus, there is a current research effort to find highly efficient and enantioselective catalysts based on earth abundant metals for more economical and safer processes without sacrificing activity and selectivity. Recently, iron has received a large amount of attention as a viable catalyst for both asymmetric transfer hydrogenation (ATH $)^{3}$ and direct hydrogenation $(\mathrm{DH})^{4}$ of polar double bonds. ATH takes place in the presence of a sacrificial reductant as the $\mathrm{H}^{+} / \mathrm{H}^{-}$source, as shown in Scheme 1 with isopropanol as the reductant. This transformation will be the focus of this communication.

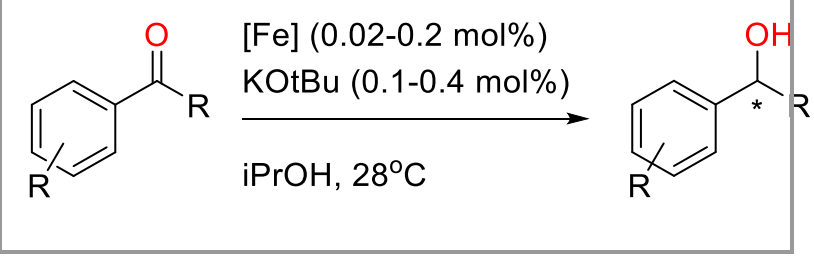

Scheme 1: General reaction scheme for the ATH of ketones
Three iron(II) complexes (1-3 in Figure 1) of our iron catalysts for ATH have been synthesized and reported recently. ${ }^{3 \mathrm{~m}, 4 \mathrm{ff}}$ Complex 1 was found to be highly active in the ATH of ketones with enzyme-like activity. Turnover frequencies (TOF) up to $200 \mathrm{~s}^{-1}$ and enantiomeric excess (ee) up to $90 \%$ was observed for the reduction of 3,4-bis(trifluoromethyl)acetophenone (K8). Although complex 1 has unprecedented activity, there is room for improvement with respect to enantioselectivity. Complex $\mathbf{2}$ has lower activity but provides higher ee (up to $98 \%$ ) for certain substrates. In some cases there is racemization of the product near the end of the reaction. Complex $\mathbf{3}$ has higher activity but lower enantioselectivity.

In the preparation of the catalyst, the incorporation of an $\mathrm{N}-\mathrm{H}$ moiety in the tetradentate ligand required an intensive synthetic approach where first an enantiomerically pure $(S, S)$ -

$\mathrm{R}_{2} \mathrm{PCH}_{2} \mathrm{CH}_{2} \mathrm{NHCH}(\mathrm{Ph}) \mathrm{CH}(\mathrm{Ph}) \mathrm{NH}_{2}\left((\mathrm{~S}, \mathrm{~S})-\mathrm{P}-\mathrm{NH}-\mathrm{NH}_{2}\right)$ ligand was synthesized and isolated, then it underwent an iron-templated Schiff-base condensation with an $\alpha$ diarylphosphinoacetaldehyde to produce the PNH-N-P ligand on iron. Complexes 1-3 differ only by the aryl phosphine groups, and complex $\mathbf{3}$ is so far the only one with unsymmetrical phosphine donors. We propose that the use of a more sterically hindered phosphine such as a dicyclohexylphosphino group on the ligand may improve the enantioselectivity of this system, and this phosphine can be introduced in the final step of the templated ligand synthesis. 


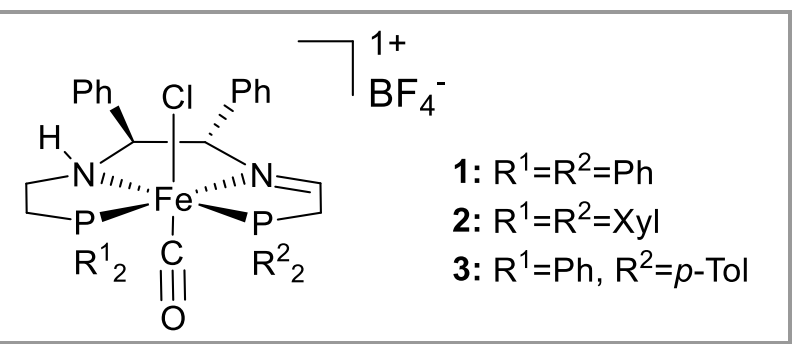

Figure 1: Third generation iron(II) complexes previously reported by our group

The present study describes the catalytic reduction of ketones using a new unsymmetrically substituted catalyst $\mathbf{4}$ which provides alcohols in excellent enantiomeric enrichment without racemization.

The new complex 4 was synthesized using a similar method to that of $\mathbf{1}$ and $\mathbf{3}$ as described briefly above. ${ }^{3 \mathrm{~m}}$ Starting with the air- and moisture-stable dicyclohexylphosphonium dimer and the enantiomerically pure $(S, S)-\mathrm{Ph}_{2} \mathrm{P}$ $\mathrm{NH}-\mathrm{NH}_{2}$ ligand, the Schiff-base condensation occurred via a metal-mediated template synthesis as shown in Scheme 2. Substitution of the two MeCN with bromide and carbonyl, followed by salt exchange with $\mathrm{NaBPh}_{4}$, afforded complex 4 in moderate yield (40\%) as a mixture of two diasteromers. It has been characterized by NMR, ESI-MS, and IR. In the ${ }^{31} \mathrm{P}\left\{{ }^{1} \mathrm{H}\right\}$ NMR spectrum, characteristic doublets at $78.38 \mathrm{ppm}$ and $47.34 \mathrm{ppm}$, as well as 76.05 ppm and $75.48 \mathrm{ppm}$ correspond to two structural isomers of the complex, the first being the major isomer (75\%/25\%). Presumably, one isomer would have its $\mathrm{C}=\mathrm{O}$ syn to the $\mathrm{N}-\mathrm{H}$ and the other anti. A carbonyl stretch $\left(v_{\mathrm{CO}}\right)$ was found at $1951 \mathrm{~cm}^{-1}$, which is typical for such a complex.

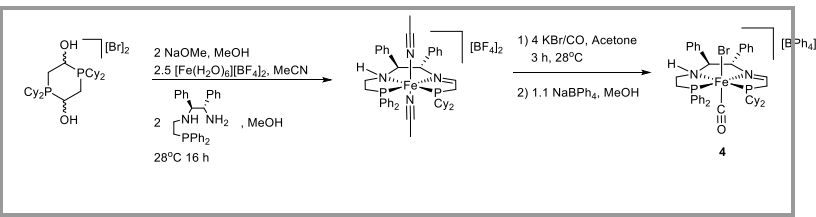

Scheme 2: Synthesis of the new iron(II) $\mathrm{Ph}_{2} \mathrm{P}-\mathrm{NH}-\mathrm{N}-\mathrm{PCy}_{2}$ complex
The catalytic activity of complex 4 was tested for the ATH of ketones K1-K16 and one aldehyde $\mathbf{A} \mathbf{1}$, shown in Figure 2 . For all substrates, the $(R)$-alcohol was produced when using our iron complexes which have enantiopure $(S, S)$-ligands. The results are summarized in Table 1. Overall, complex 4 has a lower activity than $\mathbf{1}$, however the ee of a few substrates have been increased by using the bulky dicyclohexylphosphine. Entries 1-3 show the reduction of acetophenone under different conditions. An ee of $81 \%$ was observed when the $C / B / S$ ratio was $1 / 2 / 500$, but when the catalyst loading was reduced, the ee increased significantly to $93 \%$ and $98 \%$ with 2 and 8 equivalents of base, respectively. We found that $\mathbf{4}$ was slightly less active than $\mathbf{1}$ in the reduction of $\mathbf{K 1}$, giving a conversion of $11 \%$ lower; however the ee was significantly increased by $20 \%$. In our previous work ${ }^{3 m}$ we found that complex $\mathbf{2}$ was more enantioselective for the reduction of acetophenone with a $90 \%$ ee, but 4 surpasses. Substrates K2 and K4 were reduced with very high ee of $94 \%$ and $>99 \%$, respectively; however when a more bulky substrate, such as $\mathbf{K} \mathbf{3}$ was tested, no conversion was observed. The effective reduction of $\mathbf{K} \mathbf{4}$ is noteworthy as Noyori-type catalysts do not hydrogenate it. ${ }^{5}$ When the substituents on the phenyl ring were varied as for substrates K5-K8, different effects on catalysis were observed. Complex $\mathbf{4}$ gave very high conversions of chlorosubstituted ketones $\mathbf{K 5}$ and $\mathbf{K 6}$, but there were lower conversions of methyl- and $\mathrm{CF}_{3}{ }^{-}$ substituted ketones $\mathbf{K 7}$ and $\mathbf{K 8}$. The ee of the more sterically hindered ortho- and metasubstituted $\mathbf{K 5}$ and $\mathbf{K} \mathbf{8}$ were higher (94\% and $95 \%$, respectively) than the para-substituted ketones K6 and K7. Complex $\mathbf{4}$ gave a higher ee (95\%) for substrate $\mathbf{K} 8$ than $\mathbf{1}$ (90\%), however the activity was much lower with only $38 \%$ conversion. The resulting alcohol serves as an intermediate in the synthesis of Aprepitant to combat nausea associated with cancer 
chemotherapy. ${ }^{6}$ Complex 4 was found to be imine-functional group tolerant with the high conversion of acetylpyridine (K9) to (R)- $\alpha$ methyl-2-pyridinemethanol, however catalysis stopped in the presence of the oxygenfunctionalized acetylfuran (K10).

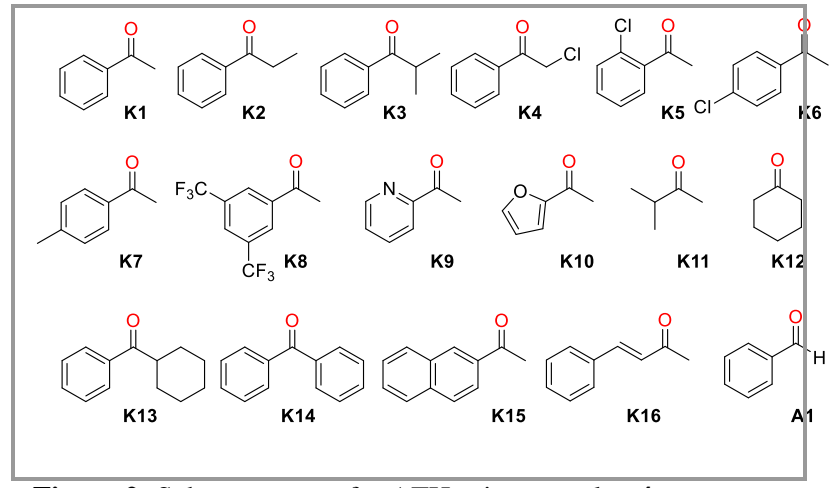

Figure 2: Substrate scope for ATH using complex 4

Alkylketones $\mathbf{K 1 1}$ and $\mathbf{K 1 2}$ are deactivated to reduction by complex 4 with conversions of $44 \%$ and $0 \%$, respectively, as is the bulky cyclohexylphenyl ketone K13. High conversions of benzophenone K14 and acetylnaphthone (K15) were observed, with an ee of $80 \%$, matching complex 1 , for the production of $(R)$ $\alpha$-methyl-2-naphthalenemethanol. The ATH of the olefinic aryl ketone $\mathrm{K} \mathbf{1 6}$ resulted in a nonselective reduction of both the $\mathrm{C}=\mathrm{O}$ and $\mathrm{C}=\mathrm{C}$ bonds with a $40 \%$ conversion to reduced products and only a $5 \%$ ee of olefin $(R)$-alcohol. This is different than complex $\mathbf{1}$ which reduced only the $\mathrm{C}=\mathrm{O}$ moiety, however with a low yield (55\%). Lastly, the hydrogenation of benzaldehyde $\mathbf{A 1 7}$ was very efficient with quantitative conversion in 10 minutes. The products of the reduction of $\mathbf{K 5}, \mathbf{K 8}$, and $\mathbf{K 9}$ were isolated via extraction from brine with ether, as well as filtration through a pad of celite. The alcohols 1-(2-chlorophenyl)ethanol and 1-(2-pyridyl)ethanol were isolated without any starting ketone present at $75 \%$ and $58 \%$ yield, and with 95 and $34 \%$ ee, respectively. The reduction of $\mathbf{K 8}$ did not go to completion, however, and the alcohol was distilled with a resulting yield of only $30 \%$ in $94 \%$ ee.

The proposed mechanism of the catalytic reaction is shown in Scheme $\mathbf{3}$ and is assumed to follow the one that has previously been reported. ${ }^{3 \mathrm{~m}}$ The precatalyst 4 is activated with 2-8 equivalents of base to form the neutral iron ene-amido species $\mathbf{5} \mathbf{a}$ and $\mathbf{5} \mathbf{b}$. It has been found that the proton and hydride of the active catalyst must be on the same side of the ligand plane, and the orientations of the amide and vacant site of 5a do not allow the initial $\mathrm{H}^{+} / \mathrm{H}^{-}$ transfer to occur in the correct way. However, complex $\mathbf{5 b}$ can dehydrogenate $\mathrm{iPrOH}$ to give the hydride complex 6 . The ketone interacts preferentially in the re configuration with $\mathbf{5 b}$ in a 6-membered transition state. The $\mathrm{H}^{+} / \mathrm{H}^{-}$ transfer then occurs to release the product alcohol and the neutral species $\mathbf{5 b}$, thus closing the catalytic cycle.

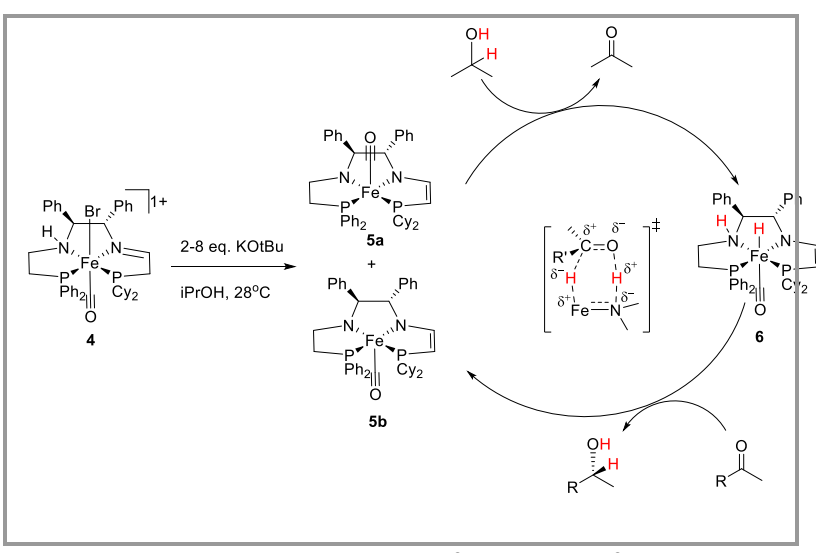

Scheme 3: Proposed catalytic cycle for the ATH of ketones

In conclusion, a newly developed unsymmetrical tetradentate P-NH-N-P' ligand has been synthesized on iron. The new precatalyst $\mathbf{4}$ was tested in the ATH of $\mathrm{C}=\mathrm{O}$ bonds and gave a TON up to 4300 and ee up to $99 \%$. In comparing the dicyclohexylphosphino-substituted complex 4 with the previously reported diphenylphosphino complex 1 in the ATH of ketones, we find that the enantioselectivity of this system is increased at the expense of catalytic activity. For example, acetophenone, usually a challenging substrate for enantioselective reduction, ${ }^{\text {le }}$ was hydrogenated with a resulting ee of $98 \%$. The flexible synthesis of 


\begin{tabular}{|c|c|c|c|c|c|}
\hline Entry & Substrate & Conversion $^{\mathrm{b}}(\%)$ & Time (min) & $\mathrm{ee}^{\mathrm{b}}(\%)$ & $\mathrm{TON}^{\mathrm{c}}$ \\
\hline 1 & $\mathrm{~K} 1$ & 83 & 20 & 81 & 415 \\
\hline $2^{\mathrm{d}}$ & $\mathrm{K} 1$ & 36 & 50 & 93 & 3550 \\
\hline $3^{\mathrm{e}}$ & K1 & 71 & 120 & 98 & 4346 \\
\hline 4 & $\mathrm{~K} 2$ & 80 & 60 & 94 & 401 \\
\hline 5 & $\mathrm{~K} 3$ & 0 & 120 & - & 0 \\
\hline 6 & K4 & 98 & 2 & $>99$ & $\sim 500$ \\
\hline 7 & K5 & $>99$ & 10 & 94 & $\sim 500$ \\
\hline 8 & K6 & 92 & 10 & 52 & 463 \\
\hline 9 & K7 & 60 & 20 & 65 & 300 \\
\hline 10 & $\mathrm{~K} 8$ & 38 & 40 & 95 & 190 \\
\hline 11 & K9 & $>99$ & 20 & 34 & $\sim 500$ \\
\hline 12 & K10 & 0 & 120 & - & 0 \\
\hline $13^{\mathrm{f}}$ & K11 & 44 & 50 & 43 & 221 \\
\hline 14 & K12 & 0 & 120 & - & 0 \\
\hline 15 & K13 & 0 & 120 & - & 0 \\
\hline 16 & K14 & 92 & 30 & - & 462 \\
\hline 17 & K15 & 88 & 20 & 80 & 440 \\
\hline 18 & K16 & 40 & 20 & 5 & 200 \\
\hline $19^{\mathrm{f}}$ & A1 & $>99$ & 10 & - & $\sim 500$ \\
\hline \multicolumn{6}{|c|}{${ }^{\text {a }}$ catalyst/base/substrate $(\mathrm{C} / \mathrm{B} / \mathrm{S})$ ratio $=1 / 2 / 500$ unless otherwise stated. } \\
\hline \multicolumn{6}{|c|}{ b \%conversion and \%ee determined by chiral GC } \\
\hline \multicolumn{6}{|c|}{${ }^{\mathrm{c}}$ turnover number } \\
\hline \multicolumn{6}{|c|}{${ }^{\mathrm{d}} \mathrm{C} / \mathrm{B} / \mathrm{S}=1 / 2 / 6121$} \\
\hline \multicolumn{6}{|c|}{${ }^{\text {e }} \mathrm{C} / \mathrm{B} / \mathrm{S}=1 / 8 / 6121$} \\
\hline
\end{tabular}

our third generation catalysts offers the possibility of tuning their structure for the optimum reduction of a given substrate. This is currently under investigation

\section{Experimental Section}

All manipulations were done under inert atmosphere of either nitrogen or argon using
Schlenk techniques or a glovebox, unless otherwise stated. Solvents were dried and degassed under standard procedures prior to use. IR spectra were recorded with samples in $\mathrm{KBr}$ disks on a Paragon 500 spectrometer. NMR spectra were recorded at ambient temperature and pressure using Agilent DD2 $600 \mathrm{MHz}$ spectrometer $\left[{ }^{1} \mathrm{H}(600 \mathrm{MHz})\right.$ and $\left.{ }^{31} \mathrm{P}\left\{{ }^{1} \mathrm{H}\right\}(242 \mathrm{MHz})\right]$. The ${ }^{31} \mathrm{P}$ NMR spectra were referenced to $85 \% \mathrm{H}_{3} \mathrm{PO}_{4}(0 \mathrm{ppm})$. The electrospray 
ionization mass spectrometry (ESI-MS) data were collected on an $\mathrm{AB} / \mathrm{Sciex}$ QStar mass spectrometer with an ESI source.

Synthesis of trans- $(S, S)-$
$\left[\mathrm{Fe}(\mathrm{Br})(\mathrm{CO})\left(\mathrm{PPh}_{2} \mathrm{CH}_{2} \mathrm{CH}_{2} \mathrm{NHCHPhCHPhN}=\mathrm{C}\right.\right.$

$\left.\left.\mathbf{H C H}_{2} \mathbf{P C y}_{2}\right)\right]\left[\mathrm{BPh}_{4}\right]$ (4): In the glovebox, sodium methoxide $(64 \mathrm{mg}, 1.176 \mathrm{mmol}$ ) was added to a 100 $\mathrm{mL}$ Schlenk flask charged with a stir bar and dicyclohexyl phosphonium bromide $(378 \mathrm{mg}$, $5.88 \times 10^{-1} \mathrm{mmol}$ ) and $25 \mathrm{~mL}$ methanol was added with stirring. This solution was stirred for no more than 2 minutes. A solution of dissolved $\left[\mathrm{Fe}\left(\mathrm{H}_{2} \mathrm{O}\right)_{6}\right]\left[\mathrm{BF}_{4}\right]_{2}(496 \mathrm{mg}, 1.47 \mathrm{mmol})$ in $20 \mathrm{~mL}$ acetonitrile was added to the Schlenk flask, followed by a solution of $(S, S)$ $\mathrm{PPh}_{2} \mathrm{CH}_{2} \mathrm{CH}_{2} \mathrm{NHCH}(\mathrm{Ph}) \mathrm{CH}(\mathrm{Ph}) \mathrm{NH}_{2}$ in $10 \mathrm{~mL}$ methanol. This resulted in a purple solution. This was left to stir at room temperature for $16 \mathrm{~h}$, after which a colour change from purple to pink was observed. The solvent was removed in vacuo. $\mathrm{KBr}$ (140 mg, $4.70 \mathrm{mmol}$ ) was added to the flask which was sealed and removed from the glovebox. The flask was purged and placed under $\mathrm{CO}$ atmosphere using Schlenk techniques. $20 \mathrm{~mL}$ acetone in a syringe was removed from the glovebox and injected into the flask with stirring for 1.5 hours. The solvent was removed under vacuum and the residual orange solid was redissolved in $20 \mathrm{~mL}$ acetone while under $\mathrm{CO}$ atmosphere. This was stirred for 1 hour, after which the solvent was removed and the flask brought into the glovebox, where the remaining steps occurred. The solid residue was dissolved in $20 \mathrm{~mL}$ dichloromethane and filtered through a pad of celite, then through a $25 \mathrm{~mm}$ Syringe Filter PTFE membrane (pore size $0.45 \mu \mathrm{m}$ ). The clear orange solution was dried in vacuo, then redissolved in minimal methanol. This solution was added to a vial charged with a stir bar and $\mathrm{NaBPh}_{4}$ (402 mg, $1.294 \mathrm{mmol}$ ) dissolved in minimal methanol, from which a yellow solid precipitated. This solid was filtered off and washed with diethyl ether $(3 \times 15 \mathrm{~mL})$ and dried overnight. If the purity by NMR was not sufficient, the solid was redissolved in minimal dichloromethane and precipitated out by addition of diethyl ether. Yield: $530 \mathrm{mg}(40 \%)$

FT-IR $\left(\mathrm{KBr}, \mathrm{cm}^{-1}\right): 1951\left(v_{\mathrm{CO}}\right)$

HRMS (ESI-TOF, $\mathrm{CH}_{2} \mathrm{Cl}_{2}$ ) $\mathrm{m} / \mathrm{z}$ calculated for $\left[\mathrm{C}_{43} \mathrm{H}_{53} \mathrm{BrFeN}_{2} \mathrm{OP}_{2}\right]^{+}:$: 809.2084, found: 809.2070

${ }^{1} \mathrm{H}$ NMR (600 MHz; $\left.\mathrm{CD}_{2} \mathrm{Cl}_{2}\right) \delta: 1.19-1.94(\mathrm{~m}, 22 \mathrm{H}$, $\left.\mathrm{P}\left(\mathrm{C}_{6} \mathrm{H}_{11}\right)_{2}\right), 2.58\left(\mathrm{~m}, 2 \mathrm{H}, \mathrm{CH}_{2}\right), 2.74\left(\mathrm{~m}, 2 \mathrm{H}, \mathrm{CH}_{2}\right)$, $4.38\left(\mathrm{t}, 2 \mathrm{H}, \mathrm{PCH}_{2}, J_{\mathrm{HH}}=11.88 \mathrm{~Hz}\right), 4.76(\mathrm{t}, 1 \mathrm{H}$,
$\left.\mathrm{N}(H)(\mathrm{Ph}), J_{\mathrm{HH}}=12.14 \mathrm{~Hz}\right), 4.83(\mathrm{~m}, 1 \mathrm{H}, \mathrm{N}(H)(\mathrm{Ph}))$, 6.83-7.56 (m, 40H, $\mathrm{ArH}), 7.79(\mathrm{~m}, 1 \mathrm{H}, \mathrm{N}=\mathrm{CH})$

${ }^{31} \mathrm{P}\left\{{ }^{1} \mathrm{H}\right\}$ NMR $\left(242 \mathrm{MHz} ; \mathrm{CD}_{2} \mathrm{Cl}_{2}\right) \delta: 78.38$ and $47.34\left(\mathrm{~d}, J_{\mathrm{PP}}=33.5 \mathrm{~Hz}\right.$, isomer 1$) ;\left(\mathrm{d}, J_{\mathrm{PP}}=33.48\right.$ $\mathrm{Hz}$ ), 76.05 and 75.48 (d, $J_{\mathrm{PP}}=38.7 \mathrm{~Hz}$, isomer 2).

General procedure for ATH: Table 1 entries 1, and 4-19: A $20 \mathrm{~mL}$ vial was charged with a stir bar and complex $4\left(10 \mathrm{mg}, 8.9 \times 10^{-3} \mathrm{mmol}\right)$. The substrate $(4.43 \times 10 \mathrm{mmol})$ was added and the mixture was stirred. If the substrate is a liquid, the mixture was stirred until complex $\mathbf{4}$ was completely dissolved. $3.61 \mathrm{~g}$ iPrOH was added and the solution was stirred for 5 minutes. A stock solution of $\mathrm{KOtBu}$ $(20 \mathrm{mg}, 0.18 \mathrm{mmol})$ in $0.98 \mathrm{~g} \mathrm{iPrOH}$ was stirred until all the base was dissolved. $0.1 \mathrm{~g}$ or $0.4 \mathrm{~g}$ stock solution ( 2 and 8 eq., respectively) was diluted by $1.0 \mathrm{~g}$ or $0.7 \mathrm{~g}$ iPrOH, respectively and added to the $20-\mathrm{mL}$ vial to activate the precatalyst and start catalysis. $0.1 \mathrm{~mL}$ samples were taken via syringe and injected into teflon-sealed GC vials prepared with wet, aerated $\mathrm{PrOH}$ to quench catalysis.

General procedure for ATH: Table 1 entries 2-3: The quantity of the precatalyst was measured via a stock solution method. A concentrated stock solution was made by dissolving complex 4 (22 mg, $1.97 \times 10^{-2} \mathrm{mmol}$ ) in $6.08 \mathrm{~g}$ cold dichloromethane. After all the solid was dissolved, the solution was immediately sucked into a syringe. The solution was then divided into equal portions into several 20 $\mathrm{mL}$ vials such that each portion has $0.2 \mathrm{~g}$ of the stock solution, and then dichloromethane was removed in vacuo. These operations led to a precatalyst quantity of $6.48 \times 10^{-4} \mathrm{mmol}$ in each vial. The base was prepared by dissolving KOtBu (10 $\mathrm{mg}, 0.089 \mathrm{mmol})$ in iPrOH $(1.02 \mathrm{~g}, 1.30 \mathrm{~mL})$. iPrOH $(6.63 \mathrm{~g}, 8.44 \mathrm{~mL})$, substrate $(3.95 \mathrm{mmol})$ and a clean stirring bar were added to the vial that contains the precatalyst and the solution was stirred for 5 minutes, or until all the precatalyst was dissolved. $0.015 \mathrm{~g}$ or $0.06 \mathrm{~g}$ of the base stock solution ( 2 or 8 eq. base) was added into a vial that contains $0.546 \mathrm{~g}$ or $0.501 \mathrm{~g}$ of $\mathrm{PrOH}$, respectively, and the mixed solution was then added into the catalyst solution to start the catalytic reaction. 0.1 $\mathrm{mL}$ samples were taken via syringe and injected into teflon-sealed GC vials prepared with wet, aerated iPrOH to quench catalysis.

\section{Acknowledgment}

NSERC is thanked for a Discovery Grant to RHM. SAM thanks Digital Specialty Chemicals Ltd for an OGSST Scholarship. 


\section{References}

(1) (a) Knowles, W. S.; Noyori, R. Acc. Chem. Res., 2007, 40, 1238. (b) Blaser, H.-U.; Pugin, B.; Spindler, F. "Asymmetric Hydrogenation" in "Topics in Organometallic Chemistry: Organometallics as Catalysts in the Fine Chemical Industry" Beller, M.; Blaser, H.-U. Eds. Springer-Verlag Berlin. (c) Saudan, L. A. Acc. Chem. Res. 2007, 40, 1309. (d) Noyori, R. Adv. Synth. Catal. 2003, 345, 15. (e) Noyori, R.; Ohkuma, T. Angew. Chem. Int. Ed. 2001, 40, 40.

(2) Morris, R. H. Chem. Soc. Rev, 2009, 38, 2282

(3) (a) Chen, J. S.; Chen, L. L.; Xing, Y.; Chen, G.; Shen, W. Y.; Dong, Z. R.; Li, Y. Y.; Gao, J. X. Acta Chim. Sin. (Huaxue Xuebao) 2004, 62, 1745. (b) Sui-Seng, C.; Freutel, F.; Lough, A. J.; Morris, R. H. Angew. Chem., Int. Ed. 2008, 47, 940. (c) Mikhailine, A. A.; Lough, A. J.; Morris, R. H. J. Am. Chem. Soc. 2009 131, 1394. (d) Meyer, N.; Lough, A. J.; Morris, R. H. Chem. Eur. J. 2009, 15, 5605. (e) Zhou, S.; Fleischer, S.; Junge, K.; Das, S.; Addis, D.; Beller, M. (f) Lagaditis, P. O.; Lough, A. J.; Morris, R. H. J. Am. Chem. Soc. 2011, 133, 9662. (g) Sues, P. E.; Lough, A. J.; Morris, R. H. Organometallics, 2011, 30, 4418. (h) Yu, S.; Shen, W.; Li, Y.; Dong, Z.; Xu, Y.; Li, Q.; Zhang, J.; Gao, J. Adv. Synth. Catal. 2012, 354, 818. (i) Mikhailine, A. A.; Maishan, M. I.; Lough, A. J.; Morris, R. H. J. Am. Chem. Soc. 2012, 134, 12266. (j) Mikhailine, A. A.; Maishan, M. I.; Morris, R. H. Org. Lett. 2012, 14, 4638. (k) Prokopchuk, D. E.; Morris, R. H. Organometallics, 2012, 31, 7375. (1) Sonnenberg, J. F.; Coombs, N.; Dube, P. A.; Morris, R. H. J. Am. Chem. Soc. 2012, 134, 5893. (m) Zuo, W.; Li, Y.; Lough, A. J.; Morris, R. H. Science 2013, 342, 1080. (n) Sues, P. E.; Demmans, K. Z.; Morris, R. H. Dalton Trans. 2014, 43, 7650.

(4) (a) Berkessel, A.; Reichau, S.; von der Hoh, A.; Leconte, N.; Neudorfl, J. M. Organometallics 2011, 30, 3880. (b) Fleischer, S.; Werkmeister, S.; Zhou, S. L.; Junge, K.; Beller, M. Chem.Eur. J. 2012, 18, 9005. (c) Fleischer, S.; Zhou, S. L.; Werkmeister, S.; Junge, K.; Beller, M. Chem. Eur. J. 2013, 19, 4997. (d) Li, Y.; Yu, S.; Wu, X.; Xiao, J.; Shen, W.; Dong, Z.; Gao, J. J. Am. Chem. Soc. 2014, 136, 4031. (e) Lagaditis, P. O.; Sues, P. E.; Sonnenberg, J. F.; Wan, K. Y.; Lough, A. J.; Morris, R. H. J. Am. Chem. Soc. 2014, 136, 1367. (f) Zuo, W.; Tauer, S.; Prokopchuk, D. E.; Morris, R. H. Organometallics, 2014, 33, 5791.

(5) Xu, Y.; Docherty, G. F.; Woodward, G.; Wills, M. Tetrahedron: Asymm. 2006, 17, 2925.

(6) Brands, K. M. J. et al., J. Am. Chem. Soc. 2003, 125, 2129.

\section{Asymmetric Transfer Hydrogenation Iron}

\section{Catalyst}
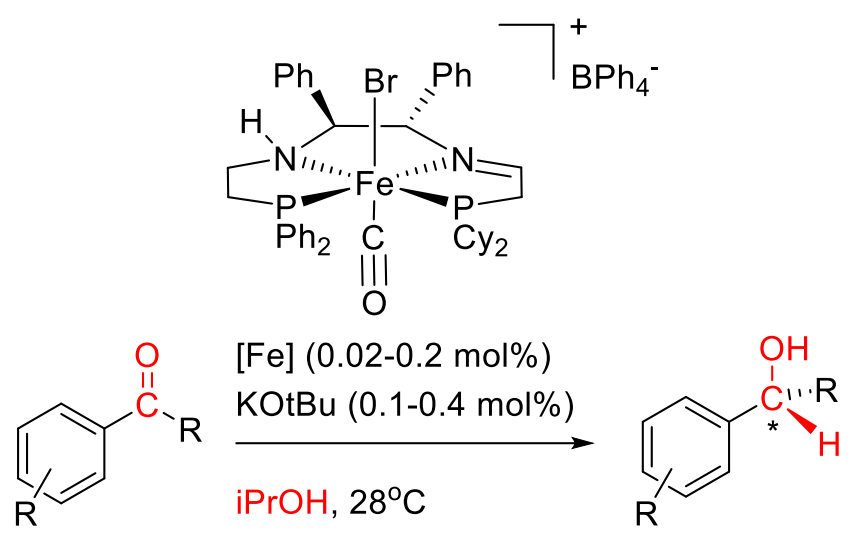

$40-99 \%$ conversion ee up to $99 \%$ 


\section{Supporting Information for}

Unsymmetrical Iron Catalyst for the Asymmetric Transfer Hydrogenation of Ketones.

Samantha A. M. Smith, Robert H. Morris*

*corresponding author. Email: robert.morris@utoronto.ca

Table of Contents:

Spectra of 1

S2

GC spectra of catalytic reactions

S5 
Figure S1 The ${ }^{1} \mathrm{H}$ NMR (600 MHz, $\left.\mathrm{CD}_{2} \mathrm{Cl}_{2}\right)$ and ${ }^{31} \mathrm{P}\left\{{ }^{1} \mathrm{H}\right\} \mathrm{NMR}\left(242 \mathrm{MHz}, \mathrm{CD}_{2} \mathrm{Cl}_{2}\right)$ spectra of 4.

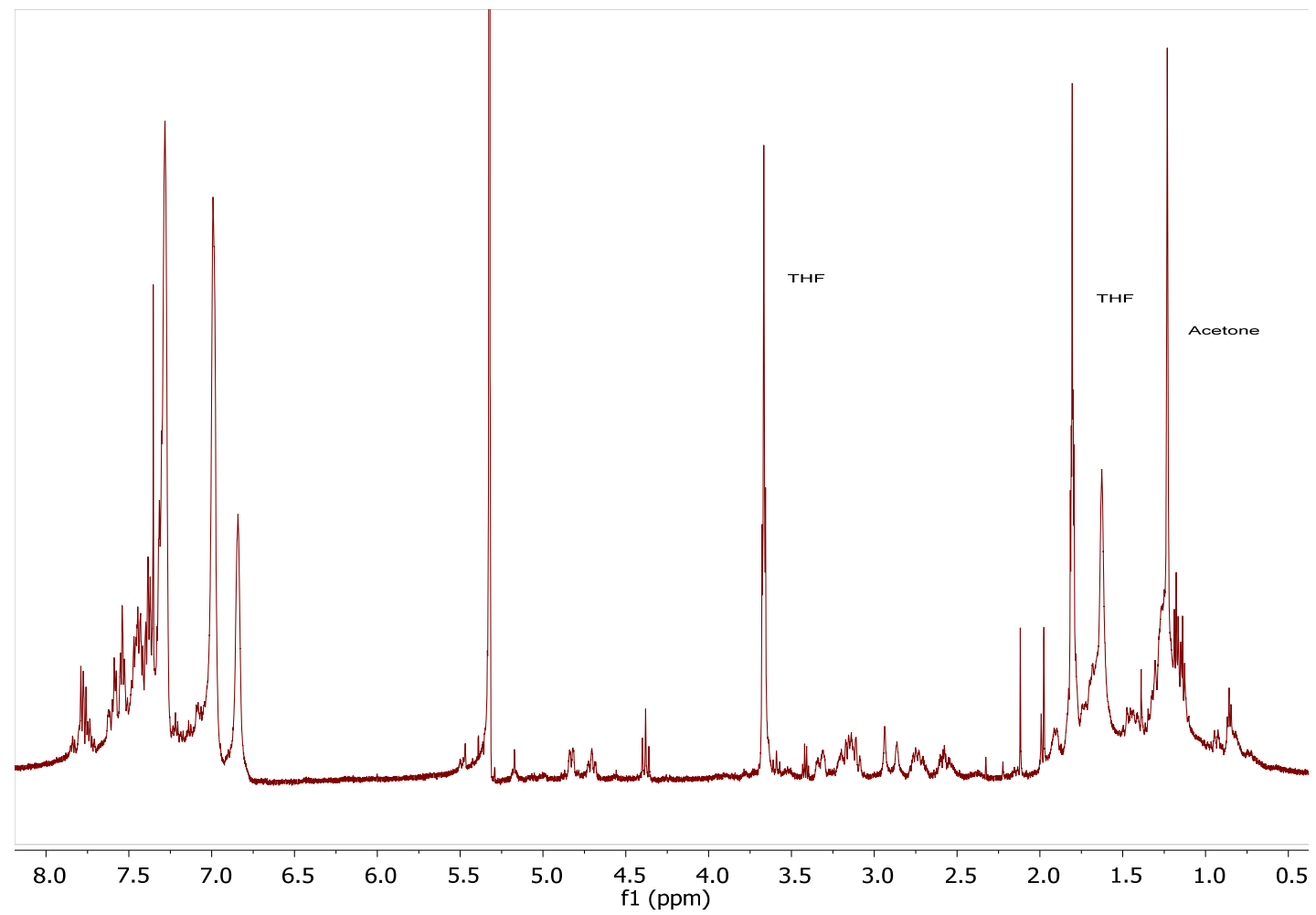




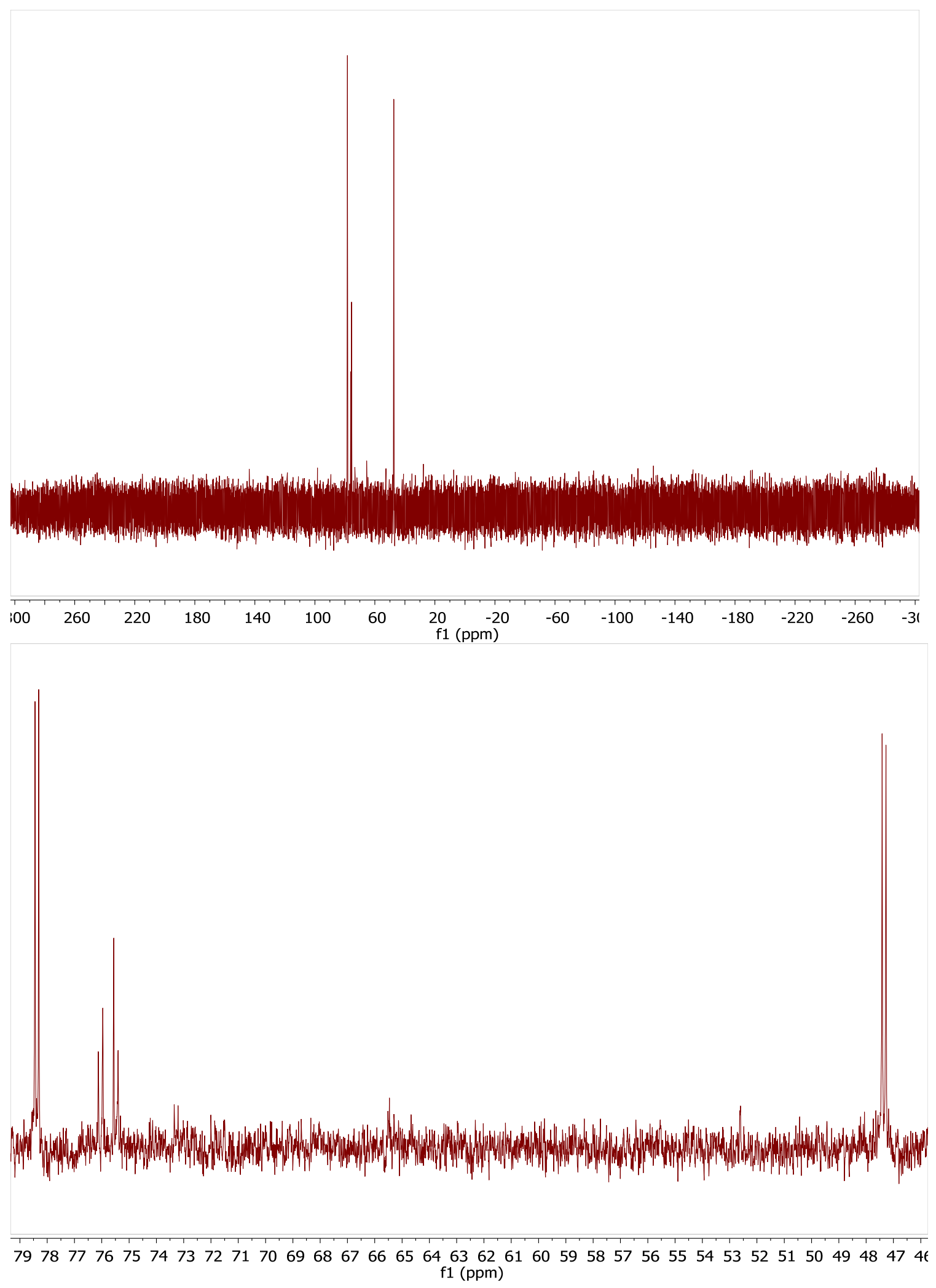


Figure S2 The FT-IR spectrum ( $\mathrm{KBr}$ pellet) of 4. The peak at $1951 \mathrm{~cm}^{-1}$ was assigned to the CO stretch.

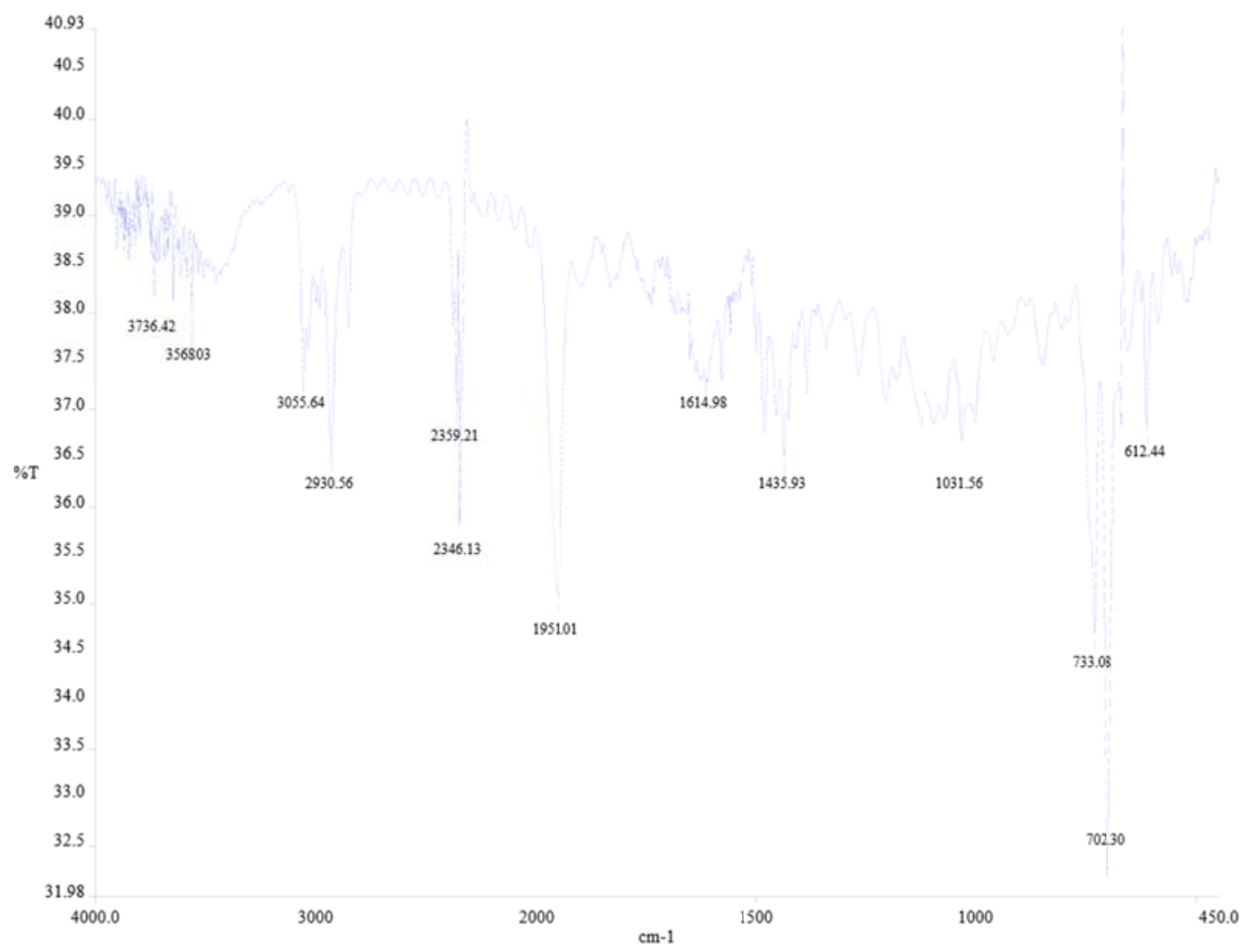


Figure S3 Entry 3 reaction profile and ee of the catalytic reduction of acetophenone.

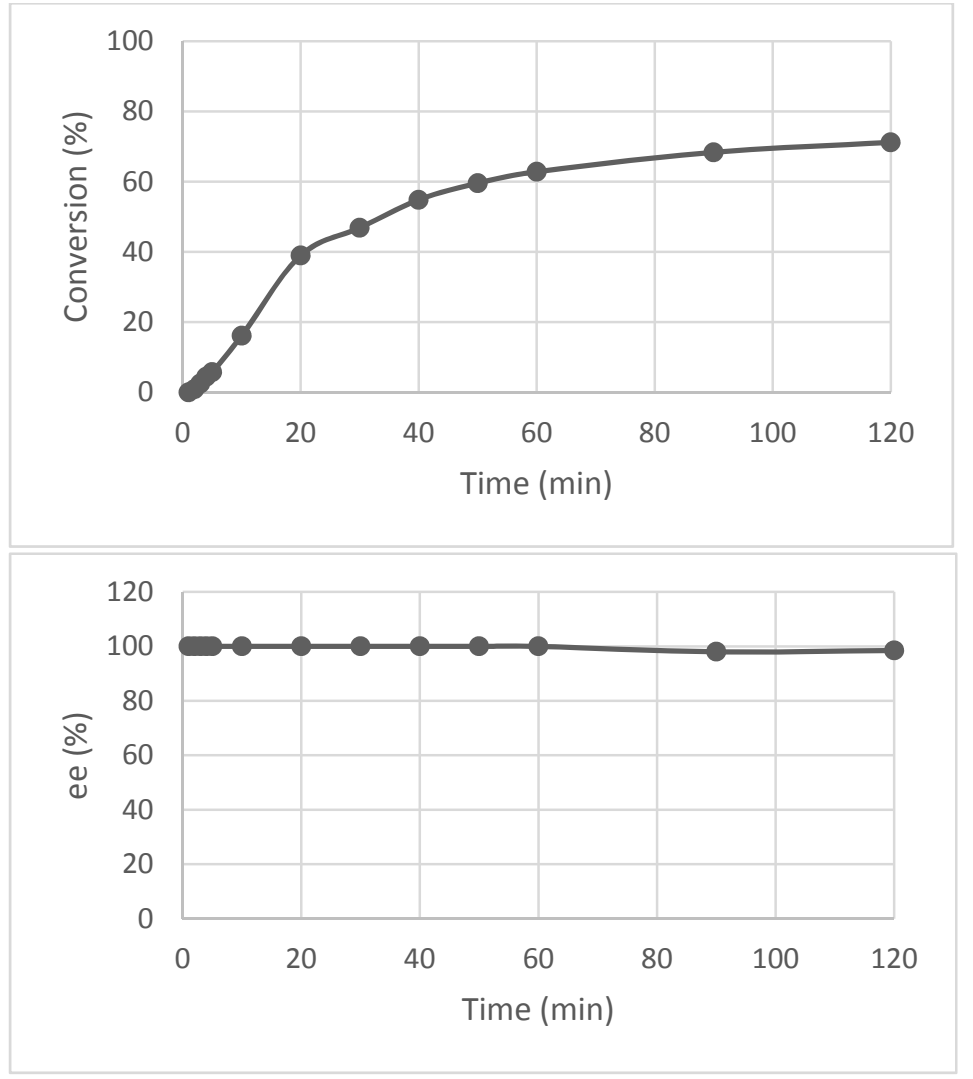


Figure S4.1 Reaction for entry 1, Table 1<smiles>CCCCOC(C)C(=O)c1ccccc1</smiles>

GC analysis conditions: Oven temperature $130^{\circ} \mathrm{C}$

Retention time: $(R)$-isomer $=6.693 ;(S)$-isomer $=7.193 ;$ starting material $=4.093$.

\section{Figure S4.2}

$10 \min$

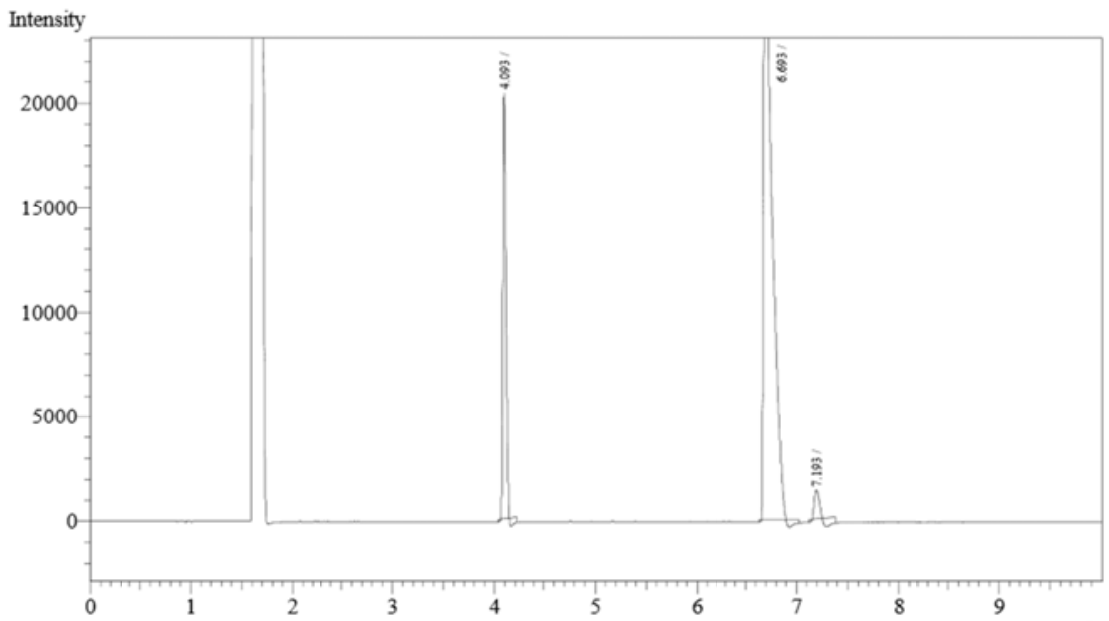

Figure S5.1 Reaction for entry 2, Table 1

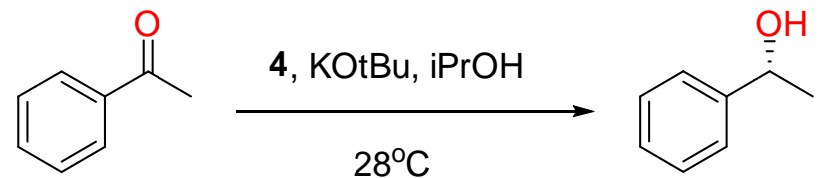

GC analysis conditions: Oven temperature $130{ }^{\circ} \mathrm{C}$

Retention time: $(R)$-isomer $=6.758 ;(S)$-isomer $=7.239 ;$ starting material $=4.072$.

Figure S5.2

$50 \mathrm{~min}$ 


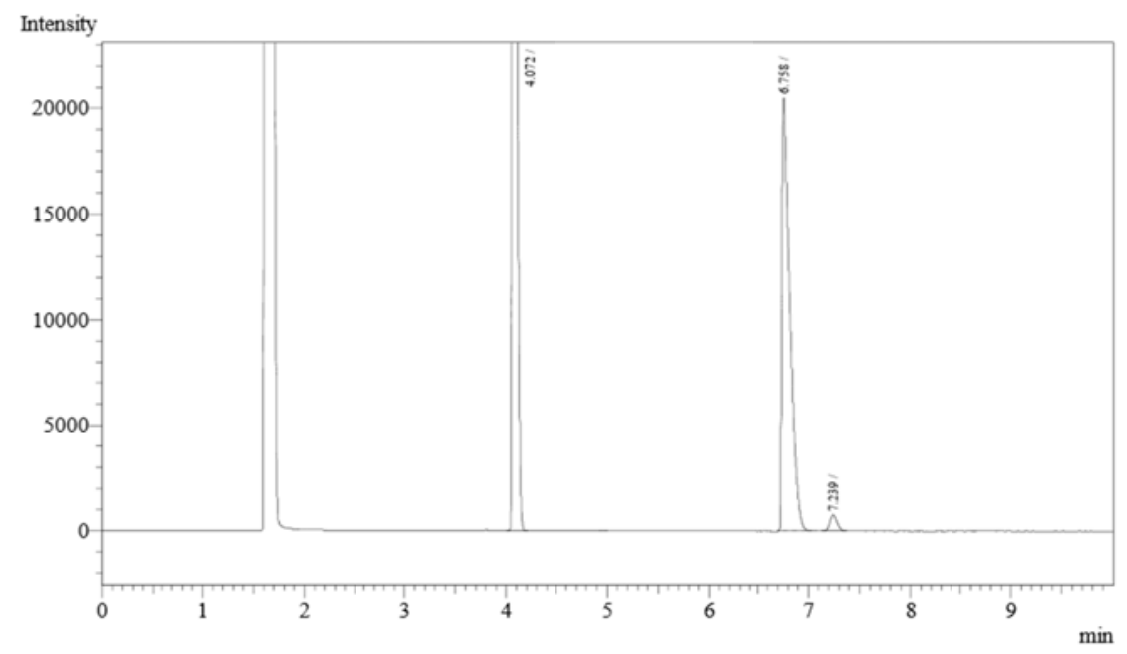

Figure S6.1 Reaction for entry 3, Table 1<smiles>CCCCOC(C)Cc1ccccc1</smiles>

GC analysis conditions: Oven temperature $130^{\circ} \mathrm{C}$

Retention time: $(R)$-isomer $=6.703 ;(S)$-isomer $=7.193 ;$ starting material $=4.092$.

\section{Figure $\mathbf{S 6 . 2}$}

$120 \mathrm{~min}$

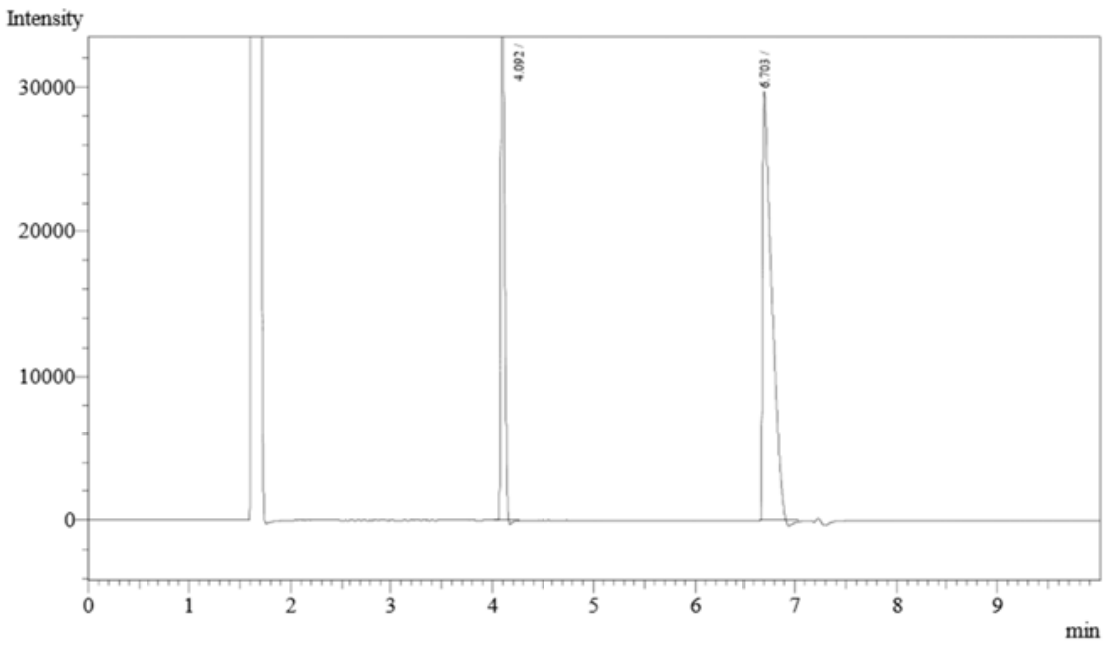

Figure S7.1 Reaction for entry 4, Table 1<smiles>CC[C@H](O)c1ccccc1</smiles> 
GC analysis conditions: Oven temperature $120^{\circ} \mathrm{C}$

Retention time: $(R)$-isomer $=10.966 ;(S)$-isomer $=11.992 ;$ starting material $=5.349$.

\section{Figure S7.2}

$60 \mathrm{~min}$

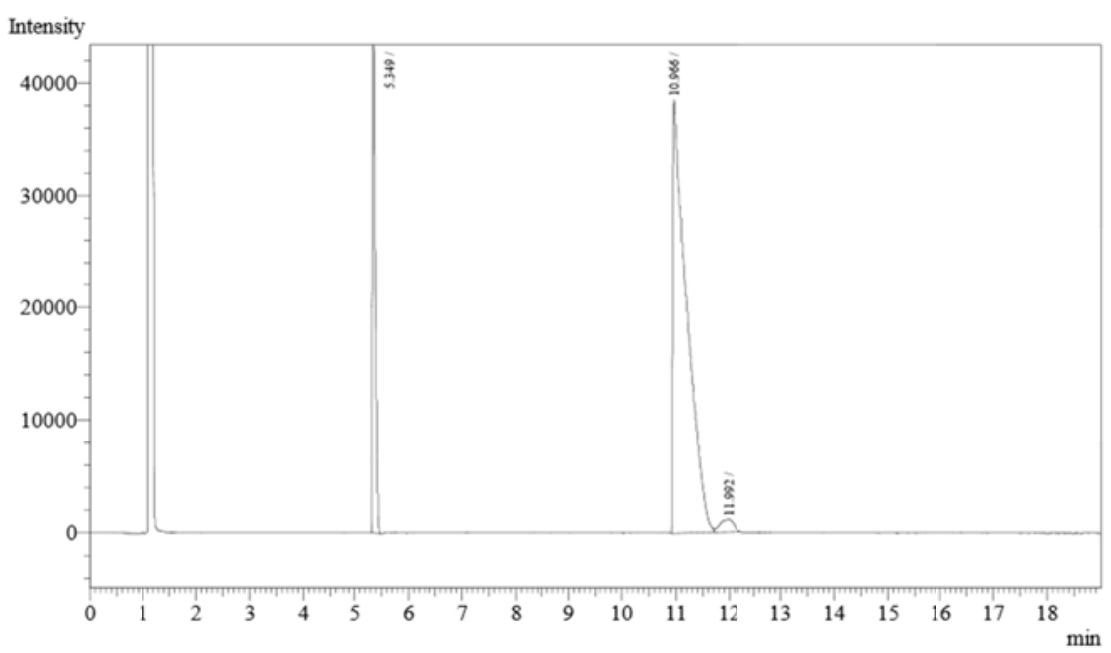

Figure S8.1 Reaction for entry 6, Table 1

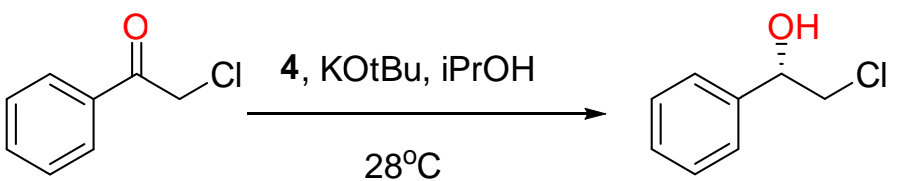

GC analysis conditions: Oven temperature $120^{\circ} \mathrm{C}$

Retention time: $(R)$-isomer $=14.530 ;(S)$-isomer $=$; starting material $=3.672$.

\section{Figure $\mathbf{S 8 . 2}$}

\section{$2 \min$}

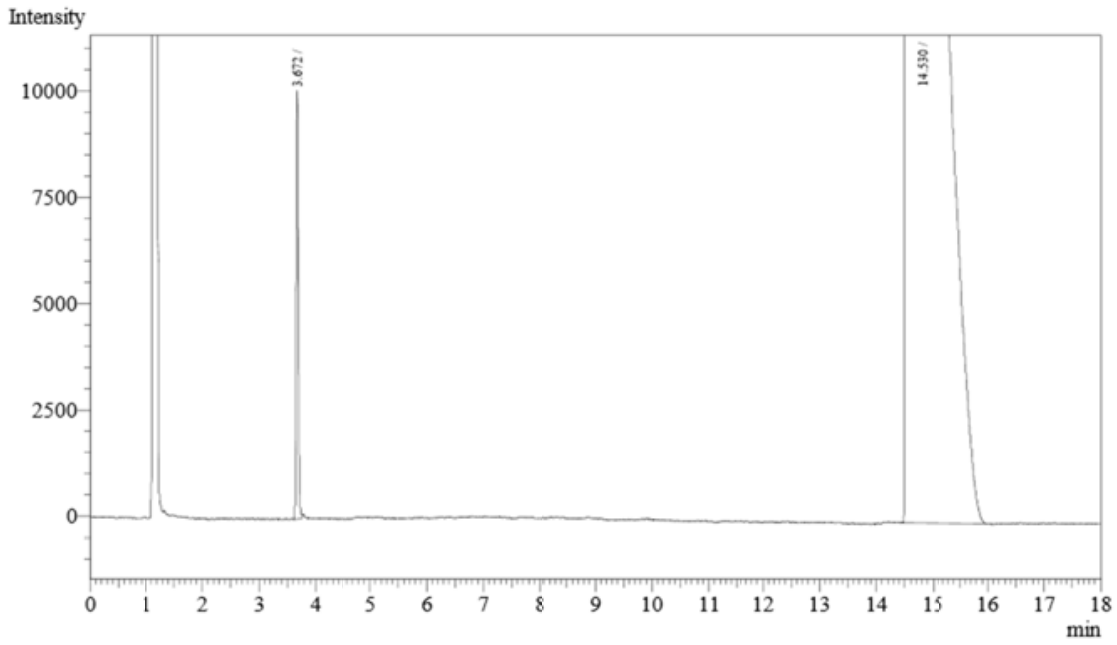


Figure S9.1 Reaction for entry 7, Table 1<smiles>CC(=O)c1ccccc1Cl</smiles>

4, $\mathrm{KOtBu}, \mathrm{iPrOH}$ $28^{\circ} \mathrm{C}$<smiles>CC(O)c1ccccc1Cl</smiles>

$\mathrm{GC}$ analysis conditions: Oven temperature $145^{\circ} \mathrm{C}$

Retention time: $(R)$-isomer $=5.654 ;(S)$-isomer $=6.924 ;$ starting material $=2.752$.

\section{Figure $\mathbf{S 9 . 2}$}

$10 \mathrm{~min}$

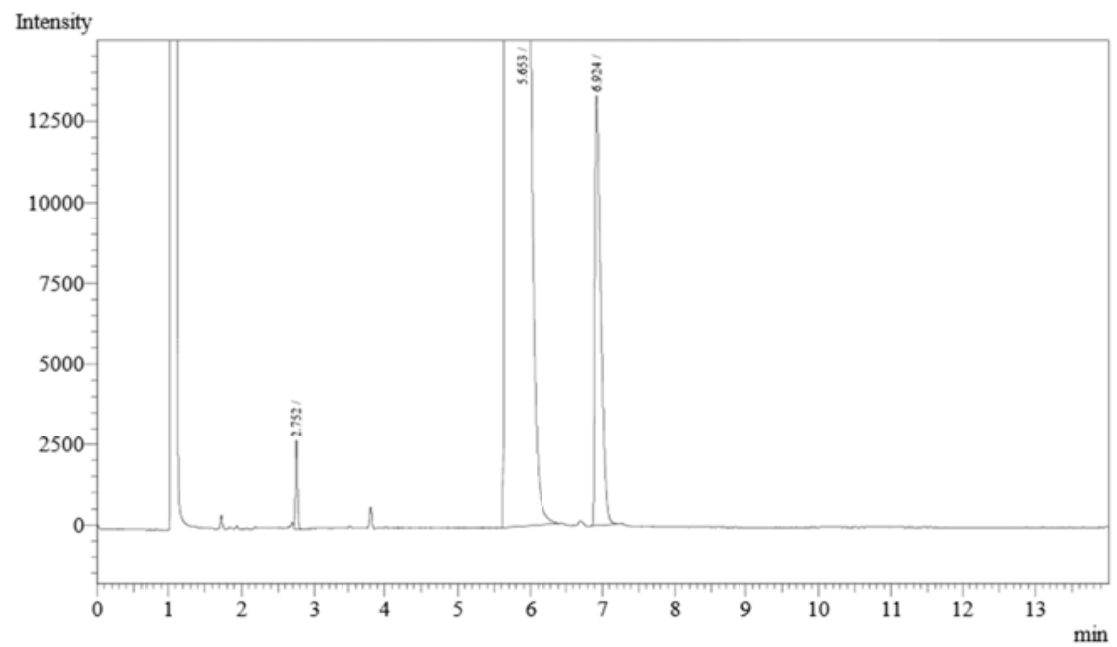

Figure S10.1 Reaction for entry 8, Table 1

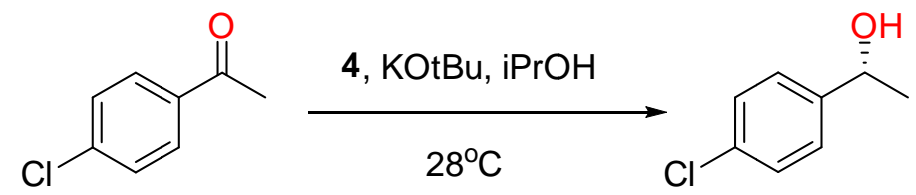

GC analysis conditions: Oven temperature $145^{\circ} \mathrm{C}$

Retention time: $(R)$-isomer $=4.737 ;(S)$-isomer $=5.213 ;$ starting material $=2.588$.

\section{Figure S10.2}

$10 \mathrm{~min}$ 


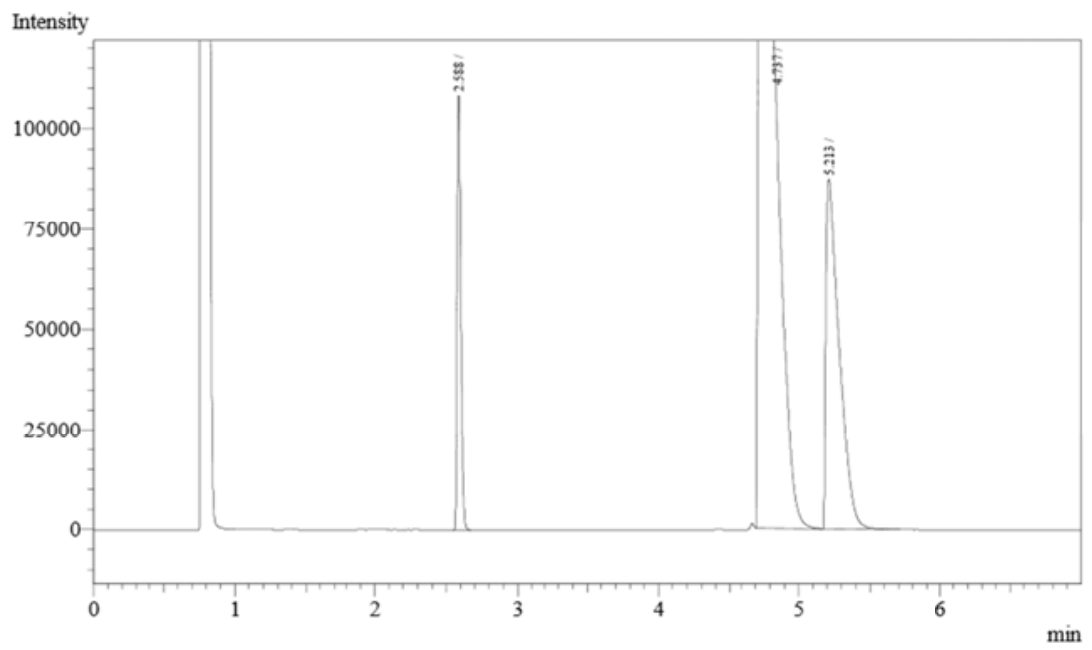

Figure S11.1 Reaction for entry 9, Table 1

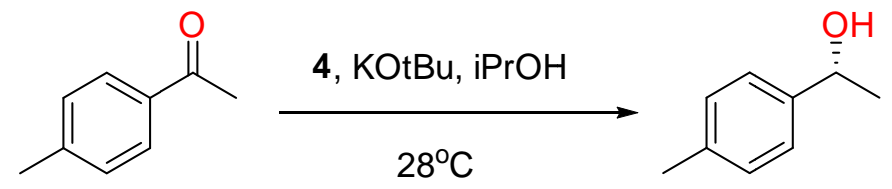

GC analysis conditions: Oven temperature $130^{\circ} \mathrm{C}$

Retention time: $(R)$-isomer $=;(S)$-isomer $=;$ starting material $=$.

\section{Figure S11.2}

$20 \min$

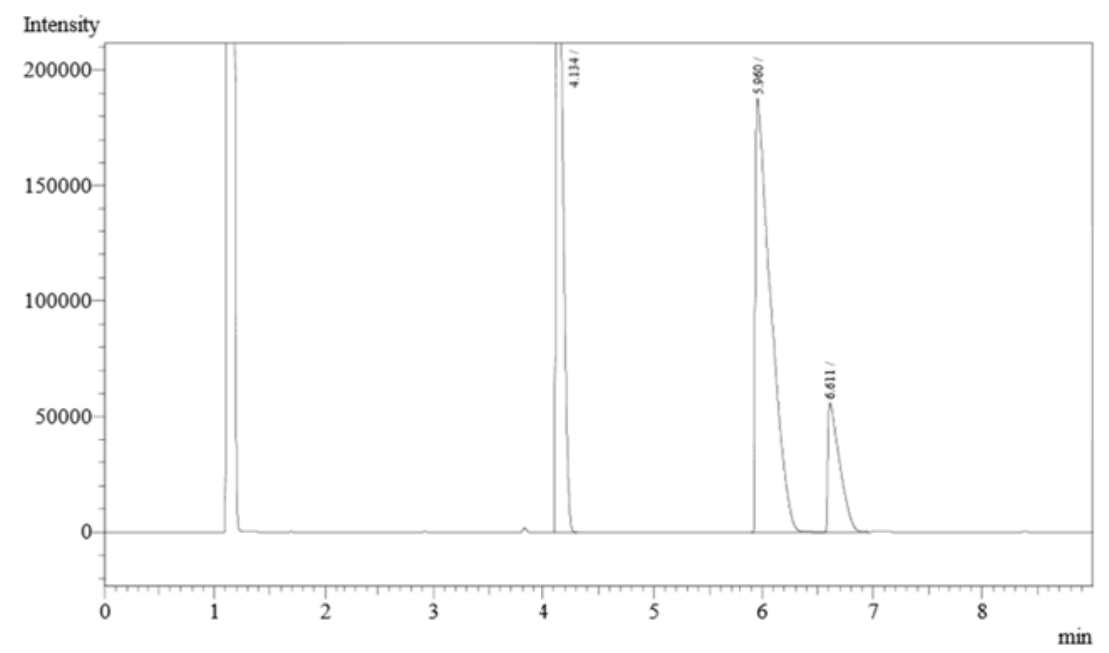

Figure S12.1 Reaction for entry 10, Table 1 


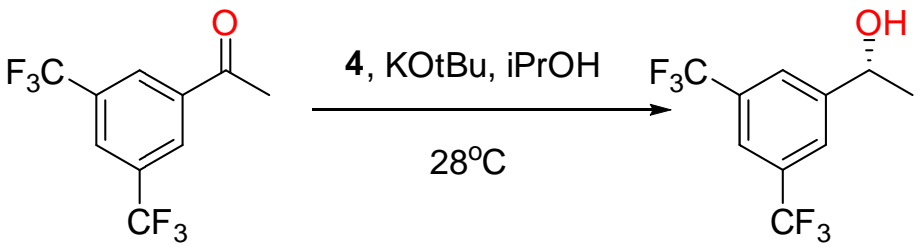

$\mathrm{GC}$ analysis conditions: Oven temperature $140{ }^{\circ} \mathrm{C}$

Retention time: $(R)$-isomer $=2.735 ;(S)$-isomer $=2.606$; starting material $=1.399$.

\section{Figure S12.2}

$40 \mathrm{~min}$

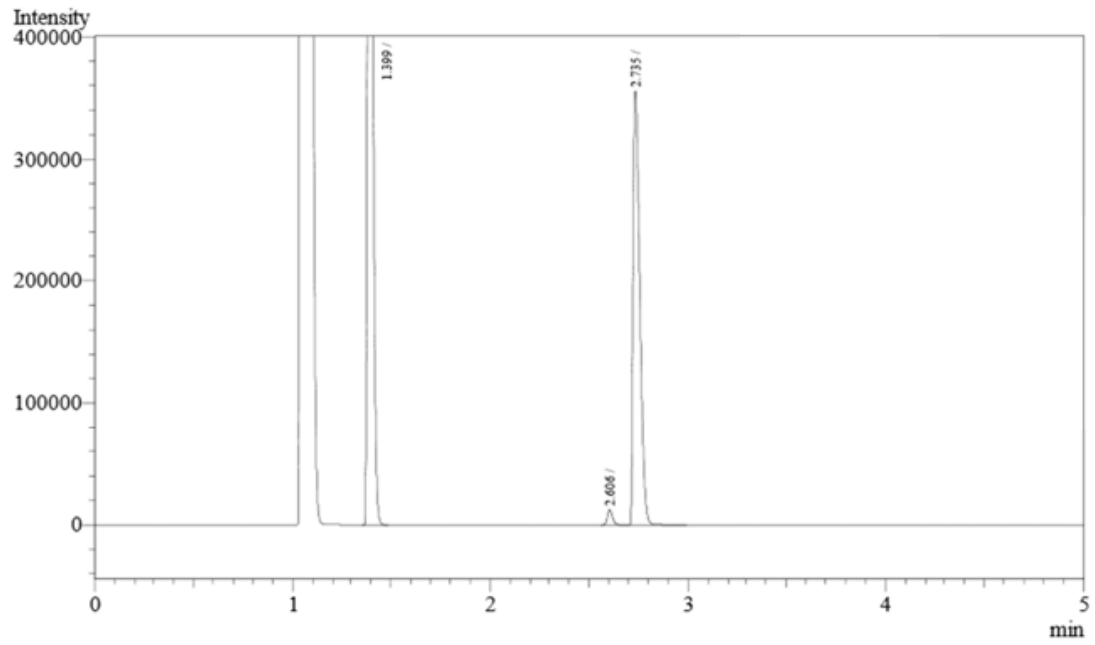

Figure S13.1 Reaction for entry 11, Table 1

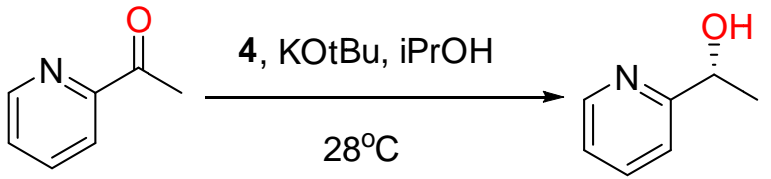

GC analysis conditions: Oven temperature $100^{\circ} \mathrm{C}$

Retention time: $(R)$-isomer $=13.779 ;(S)$-isomer $=14.208 ;$ starting material $=5.865$.

\section{Figure S13.2}

$20 \mathrm{~min}$ 


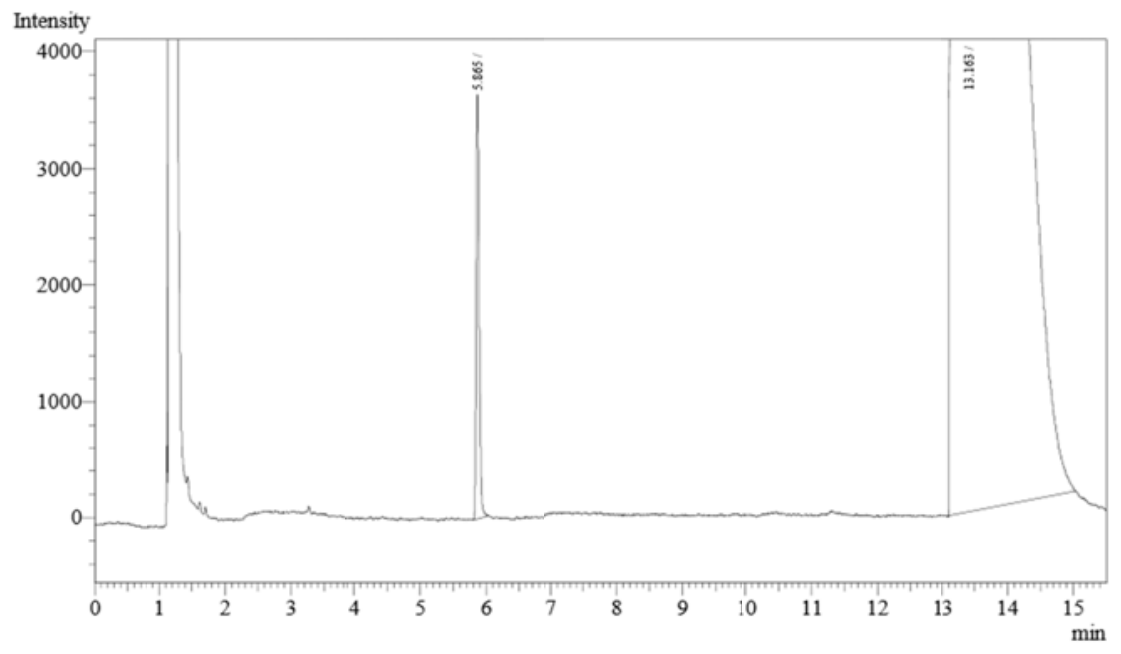

Figure 13.3

20 mins, after isolation ee was obtainable

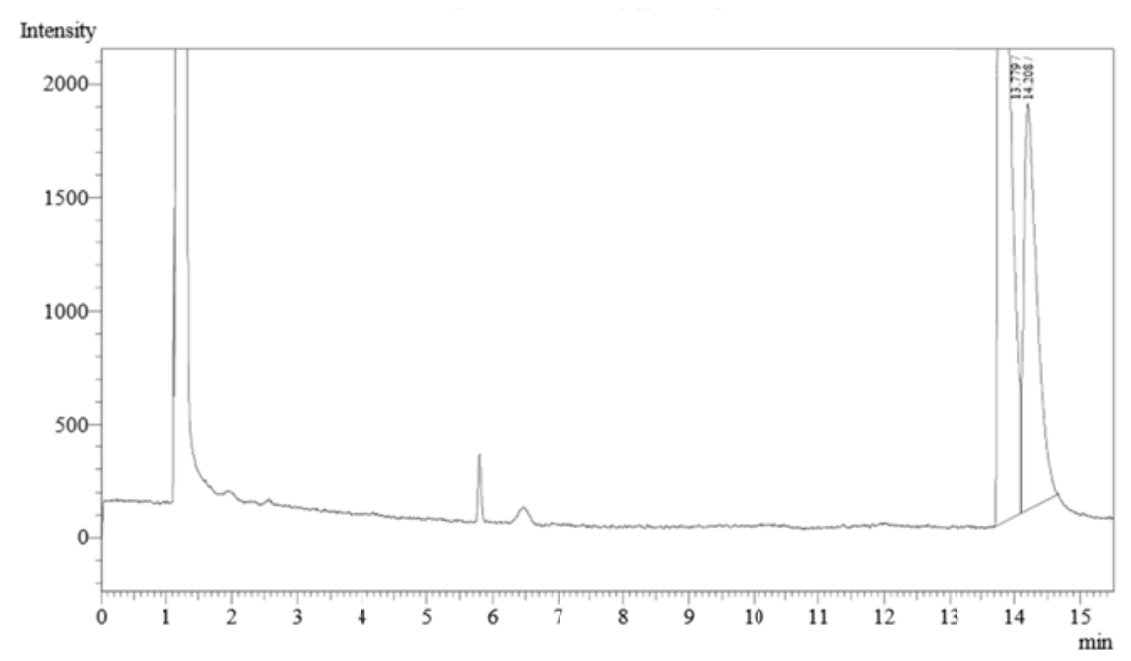

Figure S14.1 Reaction for entry 13, Table 1

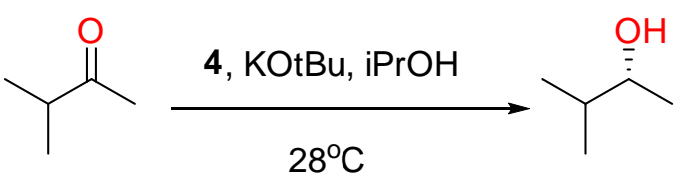

$\mathrm{GC}$ analysis conditions: Oven temperature $60^{\circ} \mathrm{C}$

Retention time: $(R)$-isomer $=9.41 ;(S)$-isomer $=9.92 ;$ starting material $=3.74$.

Figure S14.2

$50 \mathrm{~min}$ 


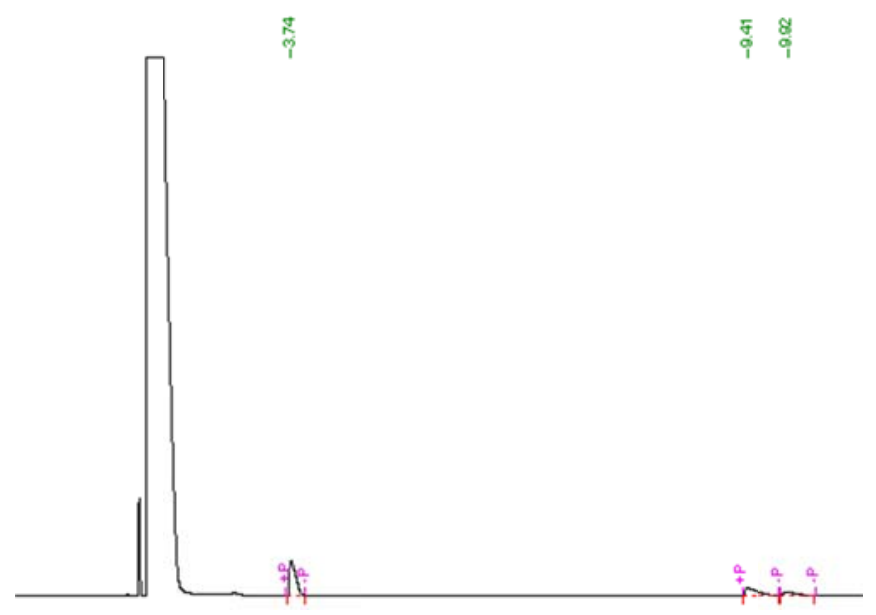

Figure S15.1 Reaction for entry 16, Table 1

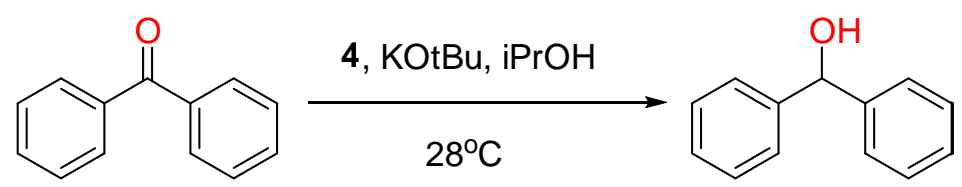

$\mathrm{GC}$ analysis conditions: Oven temperature $180^{\circ} \mathrm{C}$

Retention time: product $=5.013$; starting material $=3.228$.

\section{Figure S15.2}

$30 \mathrm{~min}$

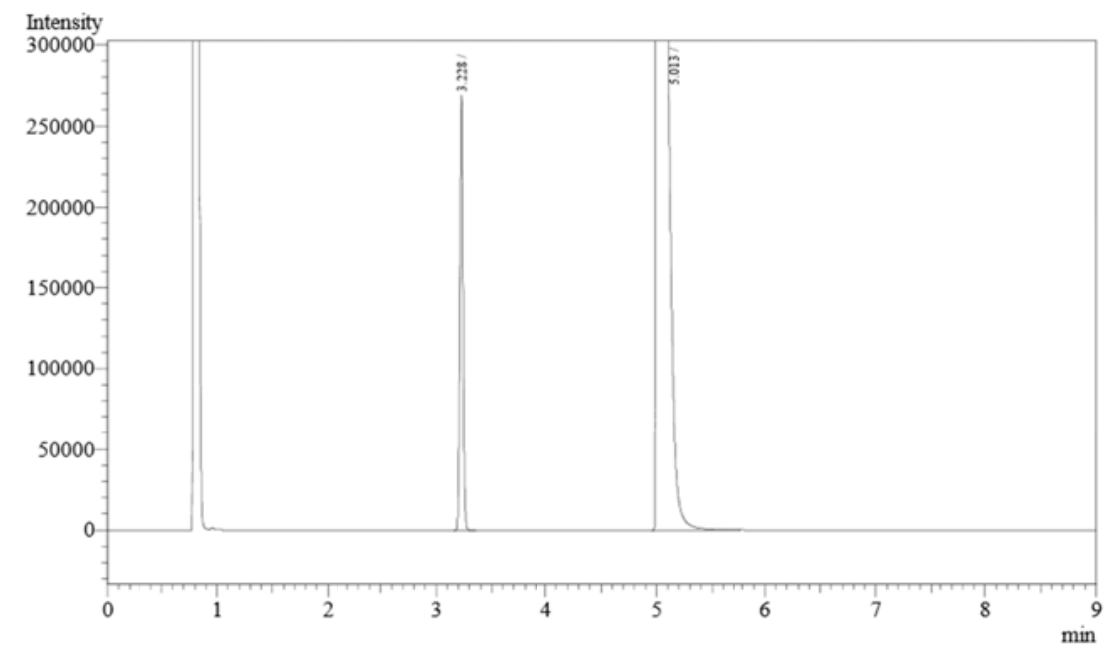

Figure S16.1 Reaction for entry 17, Table 1<smiles>CCCCC(C)OC(C)C(=O)c1ccc2ccccc2c1</smiles> 
$\mathrm{GC}$ analysis conditions: Oven temperature $150^{\circ} \mathrm{C}$

Retention time: $(R)$-isomer $=6.119 ;(S)$-isomer $=6.378 ;$ starting material $=4.403$.

\section{Figure S16.2}

$20 \mathrm{~min}$

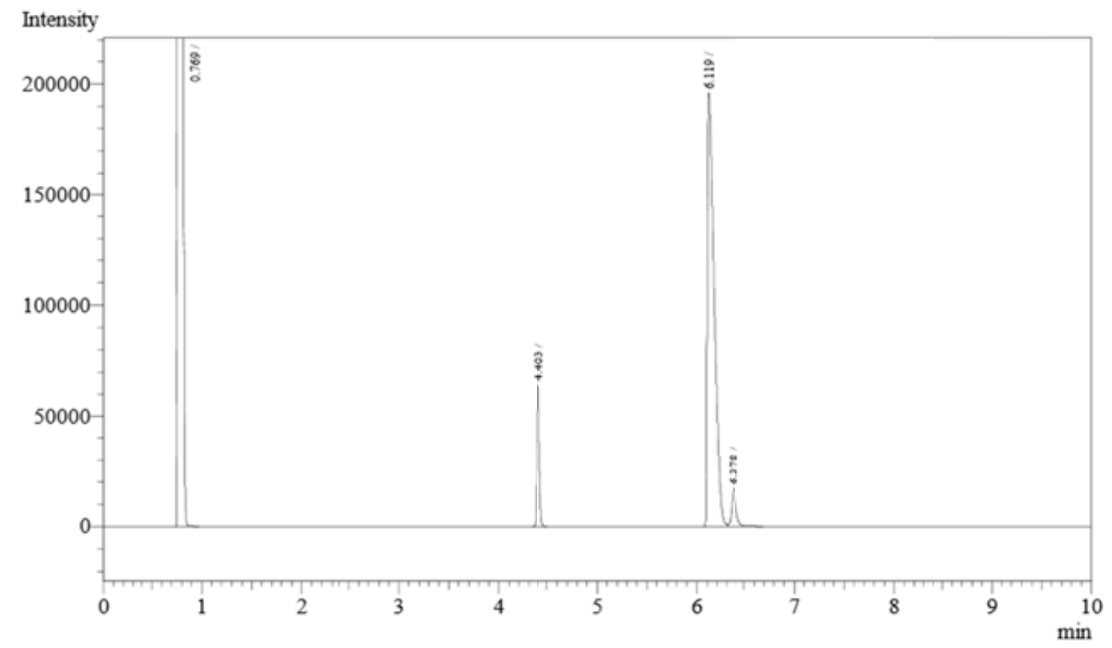

Figure S17.1 Reaction for entry 18, Table 1<smiles>CCOCCCCC(=O)CCCc1ccccc1</smiles>

$\mathrm{GC}$ analysis conditions: Oven temperature $125^{\circ} \mathrm{C}$

Retention time: $(R)$-isomer $=15.743 ;(S)$-isomer $=16.157 ;$ RED- $(R)$-isomer $=10.677 ;$ RED- $(S)$-isomer $=$ 11.051; REDK $=6.416 ;$ starting material $=12.175$.

\section{Figure S17.2}

$20 \mathrm{~min}$ 


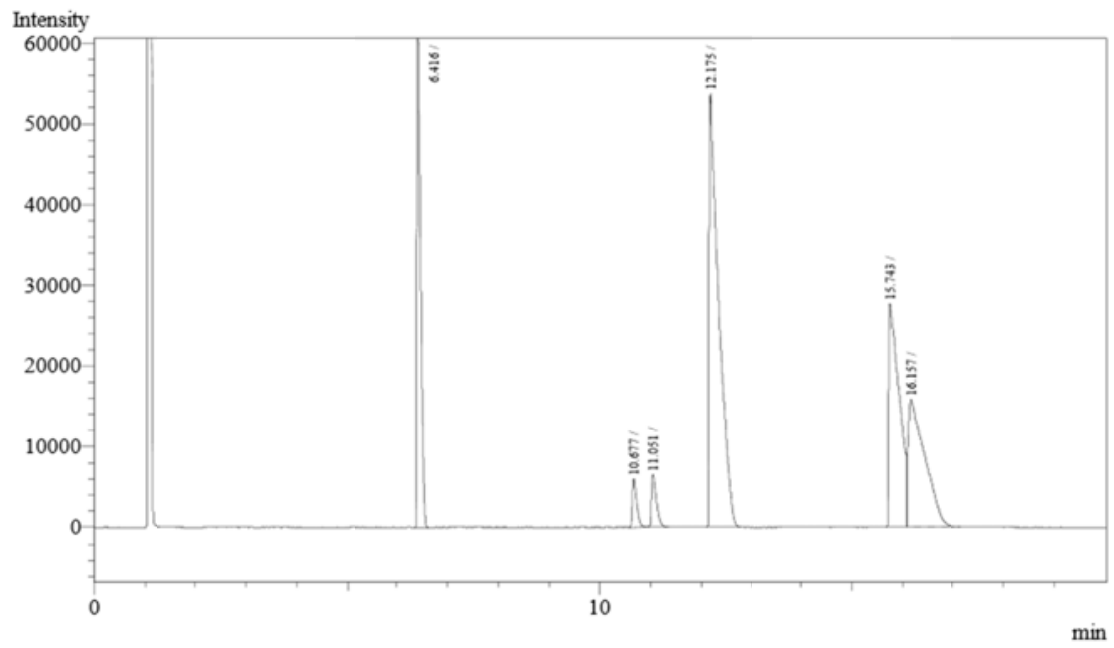

Figure S18.1 Reaction for entry 19, Table 1<smiles>CCCCCCC(=O)c1ccccc1</smiles>

$\mathrm{GC}$ analysis conditions: Oven temperature $160^{\circ} \mathrm{C}$

Retention time: product $=7.04$; starting material $=5.28$.

Figure S18.2

$10 \mathrm{~min}$

\&্口

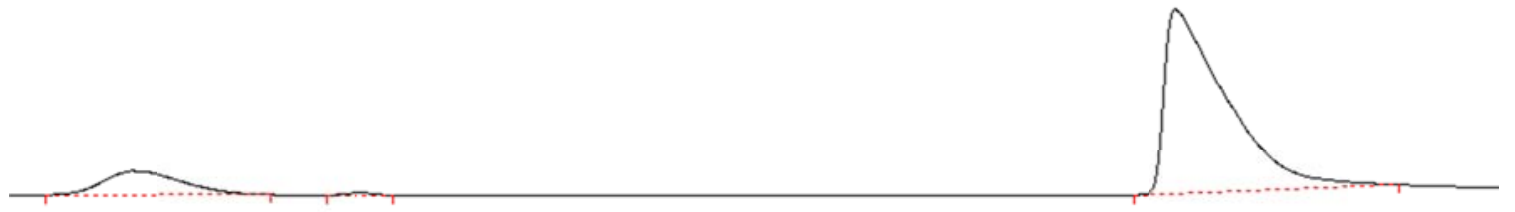

